\title{
Pengembangan Media E-Booklet Pembelajaran Berbasis Flipbook Maker pada Materi Identifikasi Karir Siswa
}

\author{
Syifa Dwi Hendrianti*, Sholeh Hidayat, Suherman \\ Program Studi Teknologi Pendidikan, Pascasarjana, Universitas Sultan Ageng Tirtayasa \\ *Corresponding Author. Email: shendrianti@gmail.com
}

\begin{abstract}
The purpose of this study was to develop an e-booklet media based on flipbook maker on career identification material for class XI students at SMKS YP 17 Cilegon. The method used is the R\&D method. This development research uses the steps developed by Borg \& Gall. There are three subjects in this study, namely material experts, media experts, and 30 students of class XI Marketing Department of Marketing. The instrument used is a validation sheet that is tested on media experts, material experts, and student responses. Based on the results of research that has been carried out at SMKS YP 17 Cilegon, it can be concluded that the development of flipbook maker-based e-booklet media has an average value of $89.28 \%$ which is categorized as very feasible with details of the percentage of media experts of $90.6 \%$, material experts of $93.7 \%$, and student responses of $83.56 \%$ so that the media is included in the appropriate category.
\end{abstract}

\begin{abstract}
Abstrak: Tujuan dari penelitian ini adalah untuk mengembangkan media ebooklet berbasis flipbook maker pada materi identifikasi karir siswa kelas XI SMKS YP 17 Cilegon. Metode yang digunakan adalah metode R\&D. Penelitian pengembangan ini menggunakan langkah yang dikembangkan oleh Borg \& Gall. Subjek dalam penelitian ini terdapat tiga yaitu ahli materi, ahli media, dan siswa kelas XI Jurusan Marketing Pemasaran berjumlah 30 siswa. Instrument yang digunakan yaitu lembar validasi yang diuji kepada ahli media, ahli materi, dan respon siswa. Berdasarkan hasil penelitian yang telah dilakukan di SMKS YP 17 Cilegon dapat disimpulkan bahwa pengembangan media e-booklet berbasis flipbook maker memiliki nilai rata-rata $89,28 \%$ yang dikategorikan sangat layak dengan rincian persentase dari ahli media sebesar 90,6\%, ahli materi sebesar 93,7\%, dan respon siswa sebesar $83,56 \%$ sehingga media tersebut masuk dalam kategori layak.
\end{abstract}

\section{Article History}

Received: 30-07-2021

Reviewed: 15-08-2021

Accepted: 10-09-2021

Published: 18-10-2021

\author{
Key Words \\ E-Booklet Media, \\ Flipbook Maker, Career \\ Identification
}

\section{Sejarah Artikel \\ Diterima: 30-07-2021 \\ Direview: 15-08-2021 \\ Disetujui: 10-09-2021 \\ Diterbitkan: 18-10-2021}

\section{Kata Kunci}

Media E-Booklet,

Flipbook Maker,

Identifikasi Karir

How to Cite: Hendrianti, S., Hidayat, S., \& Suherman, S. (2021). Pengembangan Media E-Booklet Pembelajaran Berbasis Flipbook Maker pada Materi Identifikasi Karir Siswa. Jurnal Teknologi Pendidikan : Jurnal Penelitian dan Pengembangan Pembelajaran, 6(2), 178-184. doi:https://doi.org/10.33394/jtp.v6i2.4089

\section{Pendahuluan}

Masa remaja merupakan masa peralihan dari masa anak-anak menuju masa dewasa dan salah satu tahap perkembangan dalam rentang kehidupan manusia. Masa remaja (adolescence) sebagaimasa transisi dari masa anak-anak menuju masa dewasa, dimana periode tersebut melibatkan perubahan-perubahan biologis, kognitif dan sosio-emosional (Santrock, 2007). Banyaknya perubahan yang terjadi pada masa remaja menunjukan periode penting dalam kehidupan manusia karena sikap dan perilaku yang dimiliki pada masa remaja akan memiliki dampak terhadap perkembangan di masa selanjutnya.

Perkembangan masa remaja berdampak pada kualitas keputusan karir karena kualitas keputusan karir ditentukan oleh tingkat pengetahuan identifikasi karir yang dimiliki individu. Identifikasi karir sangat dibutuhkan oleh remaja agar dapat memilih dan mempersiapkan diri 
memasuki karir dengan baik. Karir yang baik ditandai dengan kematangan karir, sehingga mampu mengambil keputusan karir (Richard, 2007).

Pemilihan karir dalam rangka mencapai keputusan karir yang baik biasanya dimulai pada saat siswa menginjak kelas XII karena siswa masuk pada tahap eksplorasi, siswa mulai mengidentifikasi kesempatan dan tingkat pekerjaan yang sesuai, serta mengimplementasikan pilihan karir dengan memilih pendidikan dan pelatihan yang sesuai dengan pilihannya supaya dapat memasuki pekerjaan yang diharapkannya.

Salah satu bentuk bantuan di lingkungan sekolah untuk memfasilitasi perkembangan peserta didik adalah melalui media pembelajaran, media pembelajaran memegang peranan yang penting dalam proses pembelajaran. Keberhasilan pembelajaran ditentukan oleh dua komponen utama yaitu metode mengajar dan media pembelajaran. Kesulitan bahan yang akan di ajarkan kepada siswa dapat disederhanakan dengan bantuan media. Media pembelajaran memiliki beberapa jenis yaitu; media pameran (Display), media cetak, media video, media audio, media visual, dan multimedia.

Kemajuan teknologi informasi banyak membawa dampak positif pada kemajuan dunia pendidikan. Keunggulan teknologi informasi yang ditawarkan bukan hanya pada faktor kecepatan mendapatkan informasiinformasi penting namun juga fasilitas media pembelajaran yang dapat membuat belajar lebih menarik.

Media e-booklet adalah media untuk menyampaikan materi-materi dalam bentuk ringkasan serta diberikan gambar yang menarik dan tidak lupa peneliti menyisipkan berbagai penanaman karakter di dalam media tersebut dengan berbasis elektronik yang dapat diakses melalui handphone dan laptop. Media e-booklet dirancang dengan menggunakan aplikasi khusus sehingga menghasilkan sebuah media pembelajaran yang dapat menarik siswa untuk menggunakannya.

Media $e$-booklet akan digunakan sebagai alat untuk memahami materi karir, sekaligus dapat memberikan minat serta kesenangan dalam menentukan karir setelah lulus dari SMK. Bisa dijadikan buku pendamping bagi siswa dalam menambah wawasan. Dengan mempelajari identifikasi karir diharapkan dapat mempersiapkan individu untuk meningkatkan kualitas hidupnya, karena dengan belajar identifikasi karir siswa dapat berpikir kritis, memecahkan masalah, dan membuat keputusan-keputusan yang ada dalam hidupnya.

Berdasarkan observasi di SMKS YP 17 Cilegon penggunaan media pembelajaran di kelas masih belum efektif khususnya dalam mata pelajaran BK materi identifikasi karir. Guru belum mempunyai inisiatif untuk membuat media BK dikarenakan guru hanya fokus dalam membuat media interaktif BK saja. Selain itu, terbatasnya ketersediaan media pembelajaran di sekolah dapat membuat kesulitan bagi guru dalam menyampaikan materi pelajaran di dalam kelas, yang akan membuat siswa sulit untuk menerima materi pelajaran yang akan diajarkan.

\section{Metode Penelitian}

Jenis penelitian ini termasuk penelitian R\&D. Menurut Sanjaya (2013) Penelitian dan Pengembangan (R\&D) adalah proses pengembangan dan validasi produk pendidikan seperti buku teks, film pendidikan, aplikasi pendidikan, dan lain sebagainya. Model pengembangan yang digunakan dalam penelitian ini adalah model Borg \& Gall. Borg \& Gall (1983) memaparkan ada sepuluh tahap dalam penelitian dan pengembangan. Penelitian dan pengembangan model Borg dan Gall dapat digunakan untuk merancang produk baru dan prosedur dikembangkan melalui beberapa tahapan secara sistematik diuji di lapangan, 
dievaluasi dan disempurnakan. Sehingga tujuan dari penelitian pengembangan memenuhi kriteria yang ditentukan seperti kualitas atau standar serta keefektifan dalam penelitian.

Lokasi penelitian adalah di SMKS YP 17 Cilegon pada semester genap tahun ajaran 2021/2022. Subjek uji coba pada penelitian ini terdapat 3 subjek yaitu ahli materi, ahli media, dan siswa kelas XI Jurusan Marketing Pemasaran yang berjumlah 30 siswa. Respons siswa bertujuan untuk mengetahui kepraktisan media pembelajaran berbasis $e$-booklet.

Teknik pengumpulan data utama dalam penelitian ini berupa penilaian produk dan observasi yang didukung dengan penggunaan wawancara, angket, dan dokumentasi. Berdasarkan hal tersebut dalam penelitian ini teknik yang digunakan adalah (1) penilaian produk berupa skala Likert untuk memvalidasi produk hingga layak digunakan; (2) observasi dilakukan dengan menggunakan rating scale untuk mengamati siswa selama proses pembelajaran menggunakan media; (3) wawancara terhadap guru terhadap media $e$-booklet yang dikembangkan; (4) angket untuk mengetahui respons pengguna mengenai kelayakan media $e$-booklet yang dikembangkan. Instrumen yang digunakan dalam penelitian ini adalah pedoman angket validasi media, angket validasi materi, angket kepraktisan media, dan pedoman angket observasi.

Pada penelitian ini, skala penilaian menggunakan skala Likert dengan interval 1 sampai 4 dengan nilai terendah 1 dan nilai tertinggi 4 , berikut adalah kriteria (rubrik) penilaian dari skala untuk uji validitas dan uji respon.

Tabel 1. Kriteria Validitas Instrumen

\begin{tabular}{c|c}
\hline Rubrik & Skala Interval \\
\hline SB (sangat Baik) & 4 \\
B (Baik) & 3 \\
CB (Cukup Baik) & 2 \\
KB (Kurang Baik) & 1 \\
\hline
\end{tabular}

Setelah menjumlahkan dan mengelompokkan nilai dari jawaban yang diberikan oleh validator, kemudian peneliti menilai dengan menggunakan rumus teknik analisis data dari Suharsimi (2011) yaitu sebagai berikut:

$$
\text { Nilai }=\frac{\text { Jumlah skor yang diproleh }}{\text { Jumlah skor ideal }} \times 100
$$

Setelah diperoleh persentase dengan menggunakan rumus di atas, kemudian skor ideal dikonversikan ke dalam empat kategori penilaian. Setelah diperoleh persentase tingkat penilaian yang berupa data kuantiatif, maka dikonversikan kembali menjadi data kualitatif. Menurut Suharsimi (2011) pengklasifikasian skor penilaian yaitu sebagai berikut:

Tabel 2. Pedoman Pengklasifikasian Skor Penilaian

\begin{tabular}{c|c}
\hline Nilai & Kriteria \\
\hline $76-100$ & Sangat Baik \\
$51-75$ & Baik \\
$26-50$ & Cukup Baik \\
$<26$ & Kurang Baik
\end{tabular}

Berdasarkan langkah-langkah di atas, dalam penelitian ini kriteria nilai kelayakan produk yang harus diperoleh dengan minimal "B" dengan kategori "Baik". Jika hasil penilaian akhir secara keseluruhan baik itu penilaian ahli media, ahli materi, dan peserta didik berada pada kategori "Baik". Multimedia interaktif yang dikembangkan telah memenuhi standar kriteria 
penilaian dan dapat digunakan sebagai sumber belajar dalam layanan bimbingan karir untuk materi identifikasi karir.

\section{Hasil Penelitian dan Pembahasan}

Proses pembuatan media $e$-booklet berbasis flipbook maker melalui beberapa tahap penelitian dan pengembangan. Tahap penelitian diawali dengan analisis kebutuhan terhadap media pembelajaran yang digunakan oleh guru. Siswa lebih tertarik dengan bahan ajar yang banyak menggunakan penjelasan berupa gambar serta warna-warna yang menarik. Selama ini media yang digunakan kurang variatif sehingga siswa terkesan bosan dan kurang memperhatikan apa yang disampaikan oleh guru. Hasil analisis menunjukkan bahwa siswa menyukai media pembelajaran yang di dalamnya banyak menggunakan gambar serta tampilan yang lebih menarik, siswa juga mengalami kesulitan apabila materi yang diterima terlalu banyak, selain itu siswa lebih tertarik dengan teknik pembelajaran terpusat pada guru dan diskusi. Penyajian booklet ini menggunakan banyak gambar daan warna sehingga memberikan tampilan yang menarik. Siswa cenderung menyukai bacaan yang menarik dengan sedikit uraian dan banyak gambar atau warna. Media pembelajaran yang dikembangkan berdasarkan analisis kebutuhan yaitu media e-booklet berbasis Flipbook Maker, media $e$-booklet berbasis Flipbook Maker dikembangkan menggunakan aplikasi Flip PDF Professional.

Tahap selanjutnya adalah tahap pengembangan media e-booklet pembelajaran berbasis Flipbook Maker yang diawali dengan validasi oleh tim ahli yaitu ahli materi, dan ahli media. Tahap ini bertujuan memvalidkan media pembelajaran yang dikembangkan sebelum diujicobakan. Tahap selanjutnya adalah pra ujicoba soal evaluasi pada 30 siswa kelas XI SMKS YP 17 Cilegon untuk dihitung uji Kelayakan. Hasil ujicoba soal dinyatakan valid, dan layak dan tingkat kesukaran sangat tinggi.

\section{Tabel 3. Analisis data rekapitulasi dari para ahli}

\begin{tabular}{c|c|c}
\hline Ahli & Presentase & Kriteria \\
\hline Ahli Media & $90,6 \%$ & Sangat Layak \\
Ahli Materi & $93,7 \%$ & Sangat Layak \\
Rata-rata & $\mathbf{9 2 , 1 5 \%}$ & Sangat Layak \\
\hline
\end{tabular}

Media pembelajaran yang telah dinyatakan Layak oleh para ahli kemudian diujicobakan pada kelompok ujicoba yaitu kelas XI SMKS YP 17 Cilegon. Pada kelompok ujicoba peneliti hanya meminta respon siswa terhadap media e-booklet berbasis Flipbook Maker. Hasil analisis respon siswa kelompok ujicoba menyatakan bahwa media e-booklet berbasis Flipbook Maker "Sangat Baik" sebagai media pembelajaran bimbingan dan konseling pada materi identifikasi karir siswa, dengan perhitungan seperti dibawah ini:

$$
\begin{aligned}
\text { Nilai } & =\frac{\text { Jumlah skor yang diproleh }}{\text { Jumlah skor maksimal }} \times 100 \\
\text { Nilai } & =\frac{1805}{(18 \times 4) \times 30} \times 100 \\
\text { Nilai } & =\frac{1805}{2160} \times 100 \\
\text { Hasil } & =83,56 \%
\end{aligned}
$$

Dengan demikian, media e-booklet berbasis flipbook maker pada materi identifikasi karir termasuk dalam kategori sangat baik. Berdasarkan hasil pemaparan penilaian siswa diperoleh skor sebesar 1805 dengan nilai 83,56 termasuk dalam kategori sangat baik. 


\section{Kesimpulan}

Proses pengembangan produk berupa media e-booklet berbasis flipbook maker dilakukan dengan mengikuti prosedur secara bertahap sesuai dengan langkah-langkah yang ada dalam model pengembangan Borg \& Gall. Produk yang dikembangkan berupa e-booklet berbentuk booklet elektronik yang dapat diakses melalui web serta dirancang menggunakan software flipbook maker yang bernama flip PDF Professional. Media e-booklet yang dikembangkan berisikan tentang materi identifikasi karir dengan mendapatkan penilaian dari ahli media, materi dan peserta didik sangat layak.

\section{Saran}

Berdasarkan hasil pembahasan penelitian dan kesimpulan dapat disarankan hal-hal sebagai berikut: (1) Hasil pengembangan media e-booklet berbasis flipbook maker diharapkan dapat digunakan dalam pembelajaran bimbingan dan konseling, sehingga akan mempermudah siswa dalam memahami materi identifikasi karir. (2) Mengingat hasil produk penelitian dan pengembangan dapat memberikan manfaat bagi proses pembelajaran, maka disarankan kepada guru untuk mengembangkan produk dengan cakupan yang lebih luas ataupun pada materi lain, bahkan pada mata pelajaran lain diwaktu mendatang. (3) Perlunya dilakukan pengembangan lebih lanjut terhadap media e-booklet berbasis flipbook maker untuk meningkatkan kualitas pembelajaran bimbingan dan konseling di SMK.

\section{Daftar Pustaka}

Ahmad Juntika Nurihsan. (2009). Strategi Layanan Bimbingan dan Konseling. Bandung: Refika Aditama.

Ali, M dan Asrori, M. (2005). Psikologi remaja perkembangan peserta didik. Jakarta: PT. Bumi Aksara.

Andi Prastowo. (2013). Panduan Kreatif Membuat Bahan Ajar Inovatif. Yogyakarta: Diva Press.

(2014). Panduan Kreatif Membuat Bahan Ajar Inovatif. Yogyakarta: Diva Press.

AR, Murniati dan Nasir Usman. (2009). Implementasi Manajamen Strategi Dalam Pemberdayaan Sekolah Menengah Kejuruan. Cita Pustaka Media Perintis, Bandung.

Arief S. Sadiman, dkk. (2012). Media Pendidikan: Pengertian, Pengembangan dan Pemanfaatannya. Jakarta: PT. Raja Grafindo Persada.

Azhar Arsyad. (2010). Media Pembelajaran. Jakarta: PT Raja Grafindo Persada. . (2016). Media Pembelajaran. Jakarta: Raja Grafindo Persada

Bly, R. (2009). Money Making Writing Job. United States of America: Soucebooks, Inc.

Borg, W.R. \& Gall, M.D. Gall. (1983). Educational Research: An Introduction, Fifth Edition. New York: Longman.

(1993). Educational Research: An Introduction, Fifth Edition. New York: Longman.

Emzir, (2013). Metodologi Penelitian Pendidikan. Depok: PT. Raja Grafindo Persada.

Darmoko. (2012). Pengaruh Media Booklet Terhadap Peningkatan Pengetahuan Petani.

Hake, RR. (1991). Analyzing Change Gain Scores. USA: Indiana University

ר___._._(1999).Analyzing Change/Gain Scores.AREA-D American Education

Research Association's Devision.D, Measurement and Reasearch Methodology.

Hamzah B. Uno. (2009). Model Pembelajaran. Jakarta: PT. Bumi Aksara. 
John W. Santrock. (2007). Perkembangan Anak. Jilid 1 Edisi kesebelas. Jakarta : PT. Erlangga.

\section{Erlangga.}

(2003). Adolescence Perkembangan Remaja. Edisi Keenam. Jakarta: PT.

Miarso, Yusufhadi . (2007). Menyemai Benih Teknologi Pendidikan. Jakarta: Prenadamedia.

Nurdiansyah. (2018). Inovasi Model Pembelajaran Sesuai Kurikulum 2013. Sidoarjo: Nizamia Learning Center

Rusman. (2012). Model-Model Pembelajaran. Jakarta: PT Raja GraFindo persada (2015)

•_. (2015). Pembelajaran Tematik Terpadu : Teori, Praktik dan Penilaian. Jakarta :

Rajawali Pres.

Sugiyono. (2003). Metode Penelitian. Bandung: Alfabeta.

• (2017). Metode Penelitian Kuantitatif, Kualitatif, dan R\&D. Bandung: Alfabeta

Sugiyono. (2013). Metode Penelitian Pendidikan Pendekatan Kuantitatif, Kualitatif, dan R\&D. Bandung: Alfabeta.

Suharsimi. (2011). Prosedur Penelitian: Suatu Pendekatan Praktik. Edisi Revisi VII. Jakarta: PT. Rineka Cipta.

Sukardi. (2007). Metodologi Penelitian Pendidikan. Jakarta: Bumi Aksara.

Sundayana. (2015). Statistika Penelitian Pendidikan. Bandung : Alfabeta.

Supriatna, Mamat. (2009). Layanan bimbingan karir di sekolah menengah. Bandung: Depdiknas dan UPI.

Widoyoko, Eko Putro. (2014). Evaluasi Program Pembelajaran Panduan Praktis bagi Pendidik dan Calon Pendidik. Yogyakarta: Pustaka Pelajar.

Wiryanto.(2004). Pengantar Ilmu Komunikasi. Jakarta : PT. Gramedia Widia Sarana

Alvarez, G. M. (2008). Career manturity: A Priority for Secondary Education. Electronic Journal of Research in Educational Psychology. ISSN. 1696-2095. No. 16. Vol. 6 (3), pp: 749-772. Spain: Departement of Educational Research Methods and Diagnostics, University of Barcelona.

Anna Fitri Ningrum,dkk. (2017). "Pengembangan Bahan Ajar Sejarah Berbentuk Booklet Pada Materi Proklamasi Kemerdekaan Indonesia dalam Upaya Peningkatan Minat Belajar Siswa Kelas XI SMAN 1 Kertek Wonosobo Tahun Pelajaran 2016/2017”, Indonesian Journal of History Education, Vol. 5 No.1.

Asvita, dkk. (2007). "Pengembangan Media Pembelajaran Booklet Pada Materi Sistem Imun Terhadap Hasil Belajar Siswa Kelas Xi Sman 8 Pontianak". Journal bioeducation, Vol. 4, No.1, Februari.

Avisha Pusvita, dkk. (2007). "Pengembangan Media Pembelajaran Booklet Pada Materi Sistem Imun Terhadap Hasil Belajar Siswa Kelas Xi Sman 8 Pontianak”. Jurnal bioeducation, Vol. 4, No.1, Februari 2007.

Ditama, Viandhika, dkk. (2015). Pengembangan Multimedia Interaktif Dengan Menggunakan Program Adobe Flash Untuk Pembelajaran Kimia Materi Hidrolisis Garam SMA Kelas XI. Jurnal Pendidikan Kimia 4 (2) : 23-31.

Erastus J. Wamalwa dan Eric Wamalwa. (2014). "Menuju Pemanfaatan Media Pembelajaran Untuk Pengajaran Yang Efektif dan Pembelajaran Bahasa Inggris ”,Kenya vol. 5 no. 31.

Juwitaningrum, Ita. (2013). Program Bimbingan Karir Untuk Meningkatkan Kematangan Karir Siswa Smk. Jurnal Psikopedagogia: Universitas Ahmad Dahlan. Vol. 2 No 1. 
Khalidiyah, H. (2015). The Use Of Animated Video In Improving Students Reading Skill (A Quasi-Experimental Study Of Seventh Grade Student At A Junior High School In Jalancagak, Subang). Journal of English and Education, 3(1), 59-79.

Nana Syaodih Sukmadinata, Op.Cit.

Meredith D. Gall, Joyce P. Gall. Walter R. Borg, Eight Edition Educational Research. New York, 2007.

Pais, R. Khushiramani, R. \& Karunasagar, I. (2007). Effect of immunostimulants on hemolymph haemagglutinins of tiger shrimp Penaeus monodon. Aquaculture Research, 38: 1339-1345.

Richard, Goerge. (2007). Career Maturity of Students in Accelerated Versus Tradisional Programs. The Career Development Quarterly Vol. 56 Iss. 2 Desember 2007.

Savickas, M. L. (2001). A Developmental Perspective on Vocational Behavior: Career Pattern, Salience, and Themes. International Journal for Educational and Vocational Guidance.

Suparman. (2010). Peran Guru dalam Penentuan Kebijakan Pendidikan dan Inovasi Pembelajaran. Jurnal Pendidikan Sejarah-AGSI.

Susilana, R., \& Ihsan, H. (2014). Pendekatan Saintifik Dalam Implementasi Kurikulum 2013 Berdasarkan Kajian Teori Psikologi Belajar 1(2). Edutech.

Tim Puslitjaknov. (2008). Metode Penelitian Pengembangan, Pusat Penelitian Kebijakan dan Inovasi Pendidikan Badan Penelitian dan Pengembangan Departemen Pendidikan Nasional. 